\title{
Late Neogene Sirius Group strata in Reedy Valley, Antarctica: a multiple-resolution record of climate, ice-sheet and sea-level events
}

\author{
Gary S. Wilson, ${ }^{1 *}$ David M. Harwood, ${ }^{2}$ Rosemary A. Askin, ${ }^{1}$ Richard H. Levy ${ }^{2}$ \\ 'Byrd Polar Research Center, The Ohio State University, Columbus, Ohio 43210, U.S.A. \\ ${ }^{2}$ Department of Geology, University of Nebraska, Lincoln, Nebraska 68588, U.S.A.
}

\begin{abstract}
Late Neogene Sirius Group strata from Tillite Spur and Quartz Hills in the Reedy Glacier area, Antarctica, demonstrate the variability in Sirius Group facies and contrasts Sirius Group strata deposited at high and low paleo-elevation, respectively. The Tillite Spur and Quartz Hills Formations (Pliocene) are formally defined here. The Tillite Spur Formation type section crops out on the edge of the Wisconsin Plateau overlooking Tillite Spur. It comprises $32 \mathrm{~m}$ of alternating coarse gray conglomerate and muddy olivebrown diamictites. The Quartz Hills Formation type section crops out above the western margin of Reedy Glacier in a pre-existing cirque towards the southern end of the Quartz Hills. It comprises c. $100 \mathrm{~m}$ of alternating massive diamictites and rhy thmically interbedded sandstone and laminated mudstones which were deposited close to sea level and subsequently rapidly uplifted $\left(>500 \mathrm{~m} \mathrm{Myr}^{-1}\right)$ to their present elevation at c. $1500 \mathrm{~m}$. Three orders of paleoclimatic variability are recorded in the Sirius Group strata from Reedy Valley: (1) recycled marine microfloras in glacial diamictites indicate intervals of marine incursion into the Antarctic cratonic interior co-occurring with reductions in the East Antarctic ice sheet; (2) an advancing and retreating paleo-Reedy Glacier deposited a glacial/interglacial sequence alternating on a 10-100 kyr scale; (3) Centimeter and millimeter stratification in strata of the Quartz Hills Formation record annual kyr scale variability.
\end{abstract}

\section{BACKGROUND}

Glacial strata in the Reedy Glacier area were first described by Mercer (1968), who referred to lithified tills and glacigene strata unconformably overlying pre-Tertiary rocks as the Horlick Drift. Later, he described similar strata from Beardmore Glacier and proposed that they be called the Sirius Formation (Mercer, 1972) and he designated the Beardmore Glacier area as the stratotype. Subsequent work has defined numerous outcrops of the Sirius Formation along the Transantarctic Mountains between Reedy and Mackay Glaciers (e.g. Mayewski, 1972, 1975; Mercer, 1978, 1981, 1983). Initially, Mercer (1968) proposed that these glacial deposits originated from local temperate glaciers in the Transantarctic Mountains. However, he later noted that only the elevated deposits (above c. $2200 \mathrm{~m}$ ) seemed to originate from local temperate glaciers and that lower-elevation Sirius Formation deposits within present-day valleys along the Transantarctic Mountains were deposited by temperate outlet glaciers from the East Antarctic ice sheet (Mercer, 1978). Because of the wide distribution, distinctive lithofacies at different locations and potential for sub-division of Sirius Formation sequences, and to aid in interpretation of the multi-phase depositional history of these widely distributed

\footnotetext{
* Present address: Institute of Geological and Nuclear Sciences, P. O. Box 30-368, Lower Hutt, New Zealand.
}

deposits, McKelvey and others (1991) elevated the Sirius Formation to the Sirius Group.

In the early 1980s, marine diatoms from distinct Cenozoic biostratigraphic assemblages (including Pliocene) were recovered from the Reedy Glacier Sirius Group strata (Harwood, 1983) and later from other Sirius Group strata along the Transantarctic Mountains (Harwood and Webb, 1986, 1991; Harwood, 1991). Webb and others (1984) suggested that these diatoms and other microfauna and microflora originated from sedimentary basins (most likely, the Wilkes and Pensacola Subglacial Basins) further inland from the Transantarctic Mountains. The diatoms were subsequently reworked into Sirius Group strata by glacial erosion, transport and deposition. The implication of this interpretation is that these sedimentary basins must have been marine seaways at times recorded by diatom flora productivity. These diatoms were subsequently recycled into the Sirius Group deposits. Hence, the East Antarctic ice sheet must have been reduced at various times in the Cenozoic (most recently in the Pliocene), and the East Antarctic ice sheet was more dynamic and sensitive to climate during the Cenozoic than previously suggested (e.g. Kennett, 1977). Regardless of the implications for a dynamic glaciation of East Antarctica, the Pliocene microflora recycled into Sirius Group strata restrict the age of deposition of such Sirius Group sequences to the late Pliocene or younger.

This interpretation of a warmer and more dynamic glacial history of the Transantarctic Mountains was reinforced by the discovery of fossil wood (Nothofagus) and in- 
situ Nothofagus leaf mats (Carlquist, 1987; Hill and others, 1991; Webb and Harwood, 1993; Hill and Truswell, 1993, Francis and Hill, 1996) within glaciolacustrine Sirius Group strata more than $1000 \mathrm{~m}$ a.s.l. in the Beardmore Glacier area. Because the growth of Nothofagus required warmer temperatures than presently exist in the Beardmore Glacier area, Webb and others $(1986,1994)$ suggested that the Nothofagus flora may have survived in coastal refugia and were subsequently uplifted. Uplift was later confirmed by Webb and others (1996) with the discovery of an in-situ foraminiferal assemblage between c. 1100 and $1200 \mathrm{~m}$ a.s.l. in strata of the Cloudmaker Formation (Sirius Group), which is considered to underlie the Nothofagus-bearing beds of the Meyer Desert Formation (Sirius Group).

Currently, the interpretation of Sirius Group deposits along the Transantarctic Mountains is causing considerable debate. Some workers use strata from the Beardmore Glacier area (e.g. Webb and others, 1984, 1994, 1996; Webb and Harwood, 1987; McKelvey and others, 1991) as their stratotype for interpretations regarding late Neogene glacial/tectonic and climate events that led to the deposition, sedimentary content and present location of Sirius Group strata high in the Transantarctic Mountains. Their studies indicate a dynamic East Antarctic ice-sheet history and rapid recent uplift of the mountains in this region, with the most recent retreat of the ice sheet in the Pliocene. Other workers have used glacial drift deposits from high in the Transantarctic Mountains of southern Victoria Land as their stratotype for interpretations regarding the tectonic and paleoclimate significance of Sirius Group strata (e.g. Denton, and others, 1984, 1993; Clapperton and Sugden, 1990; Stroeven and others, 1992, 1996; Barrett and others, 1997). These studies, along with a paleoclimate history of the Dry Valleys drawn from geomorphic surface development chronologically constrained by well-dated subaerial basalts and volcanic ash horizons (e.g. Denton and others, 1993; Wilch, 1993; Marchant and others, 1996), indicate stability of the late Neogene climate and ice sheet in East Antarctica and minimal uplift of the Transantarctic Mountains in the Dry Valleys area.

\section{SETTING}

In the Reedy Glacier area, Sirius Group strata crop out at Metavolcanic Mountain, Tillite Spur and Quartz Hills, and the latter two localities are the subject of this paper. Reedy Glacier flows northwest, adjacent to the Wisconsin Range and is the most southerly outlet $\left(85^{\circ}-86^{\circ} \mathrm{S}\right)$ of the East Antarctic ice sheet through the Transantarctic Mountains (Fig. 1). It is flanked to the west by the Queen Maud Mountains and to the east by the Horlick Mountains, both of which rise to more than 3500 ma.s.l. The Queen Maud and Horlick Mountains consist of suites of Pre-Cambrian-Ordovician metamorphic and igneous rocks, non-conformably overlain by late Paleozoic Beacon Supergroup sediments (Doumani and Minshew, 1965; Mercer, 1968).

In the upper Reedy Glacier area overlooking Tillite Spur, Sirius Group strata are exposed at c. $2500 \mathrm{~m}$ a.s.l. on the edge of the Wisconsin Plateau (Fig. 1). They form a $35 \mathrm{~m}$ sequence abutting the north wall of a small paleoglacial valley and have a southerly aspect. The southern wall of the paleoglacial valley has been removed/destroyed during down-cutting by Olentangy Glacier, whose surface is about

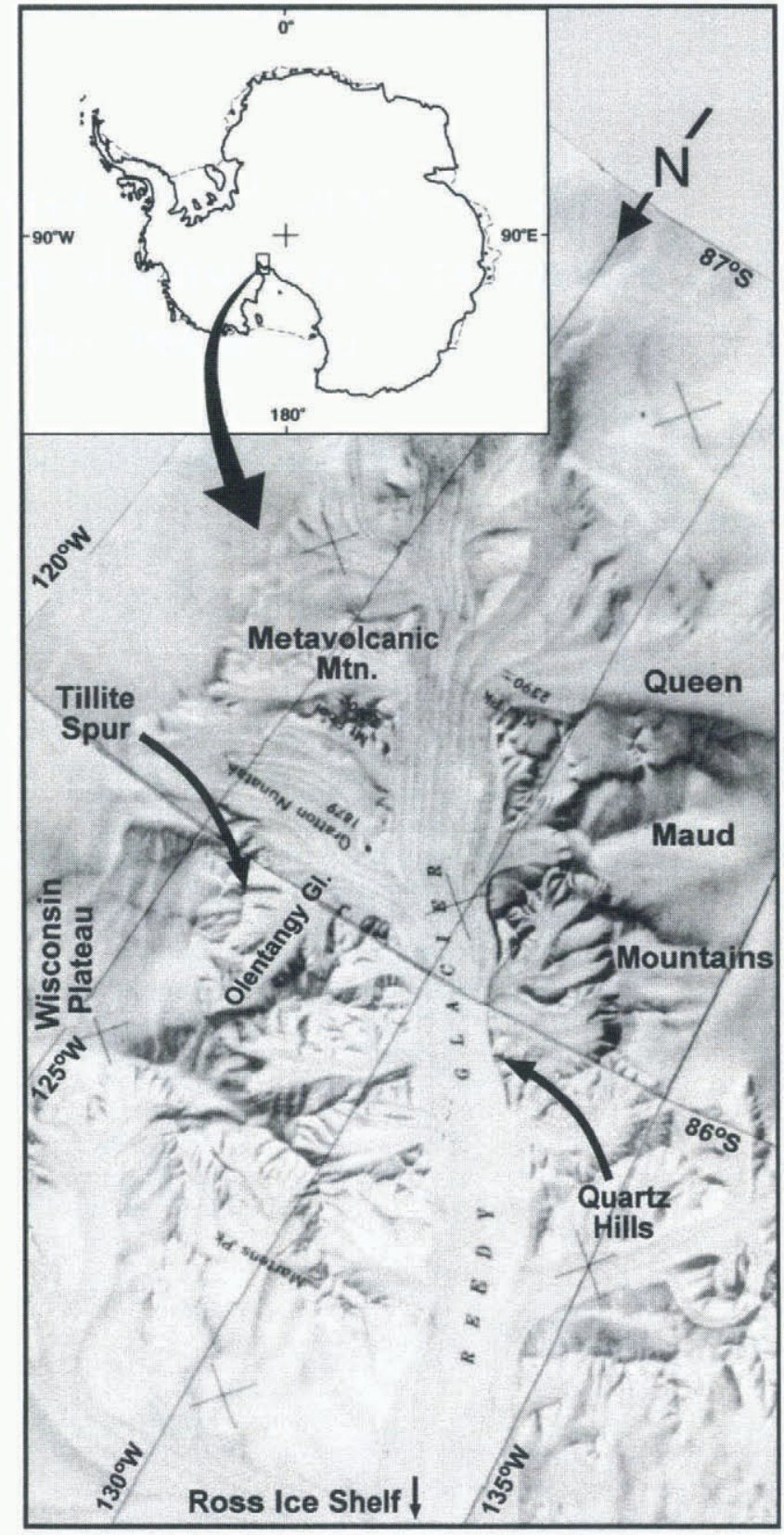

Fig. 1. Map of the Reedy Glacier area, Antartica, with the locations of Tillite Spur, Quartz Hills and other geographic features discussed in the text.

$500 \mathrm{~m}$ below Tillite Spur. Midway down Reedy Glacier at c. $1500 \mathrm{~m}$ a.s.l., Sirius Group strata at least $150 \mathrm{~m}$ thick overlie and infill a rugged topography of basement rocks at Quartz Hills. The base of the Sirius Group strata lie c. $90 \mathrm{~m}$ above the current Reedy Glacier surface and clearly pre-date the most recent down-cutting of Reedy Glacier. The best-exposed sequence infills a cirque near the southeastern end of Quartz Hills. Basal sediments of the Sirius Group sequence at Quartz Hills have been locally offset by small faults. The fault plains have well-developed slickensides and some quartzose mineralization.

\section{TILLITE SPUR FORMATION (NEW)}

Here, we propose the name Tillite Spur Formation for the lithified diamictites and conglomerates that unconformably overlie pre-Tertiary rocks on the elevated flanks of the Wisconsin Plateau. These strata were originally described as 
Horlick Drift and subdivided into six informal units by Mercer (1968) and later grouped by Mayewski (1972) with similar strata from the Beardmore Glacier area and renamed Sirius Formation (Mercer, 1972). At Tillite Spur (the type section), the $35 \mathrm{~m}$ thick sequence consists of ten lithological units (Fig. 2). The succession overlies a grooved and striated glacial pavement cross-cutting steeply dipping mudstones and sandstones of the Permian Weaver Formation (Minshew, 1966). Units 1, 3, 5 and 8 are disconformity bounded, poorly sorted, massive to faintly stratified brown/ olive-brown diamictites containing rounded to sub-rounded sedimentary and granitic clasts. The upper surface of unit 1 is very weathered and contains deep desiccation cracks $3-5$ $\mathrm{cm}$ wide. Unit 5 contains two thin undulating $(10-30 \mathrm{~cm})$ sheared olive-gray laminated mudstone horizons that are inclined locally at $20^{\circ}$. Units 2, 4, 6, 7 and 9 are disconformity bounded, poorly sorted, clast-supported conglomerates (using the classification scheme of Moncricff (1989)) containing mostly sub-rounded granitic clasts. Unit 10, the uppermost unit of the succession, is a $30 \mathrm{~cm}$ thick clast-supported conglomerate, with sub-rounded granitic clasts, that contains little to no matrix. In turn, it has been glaciated and is cross-cut by $3-5 \mathrm{~cm}$ deep west-trending glacial grooves (Fig. 3).

\section{QUARTZ HILLS FORMATION (NEW)}

These strata were originally referred to as Stratified Drift by Mercer (1968) and later grouped with the Horlick Drift into the Sirius Formation (Mercer, 1972). Here, we propose the name Quartz Hills Formation for the lithified diamictites and rhythmites (interbedded stratified mudstones and sandstones) that occur within the Reedy Glacier valley walls and unconformably overlie pre-Tertiary rocks. As defined, the formation is more than $100 \mathrm{~m}$ thick but the most continuous and representative sequence exposed at Quartz Hills is the lowermost $100 \mathrm{~m}$ of the formation. Here, we describe this and designate it as the type section. However, we note that further work will allow a more extensive composite section to be described for the entire sequence $(>150 \mathrm{~m})$ exposed at Quartz Hills. The sequence non-conformably overlies a grooved and striated undulating surface on coarse granites and Ferrar Dolerite, which has intruded the schistose rocks of the La Gorce Formation. The Quartz Hills Formation type section is subdivided into 18 lithological units (Fig. 4). Units 1, 3, 6, 9, 11, 13, 16 and 18 are poorly sorted, gravelly, massive to indistinctly stratified, gray diamictites with erosional contacts. They contain common, sub-angular to well-rounded, striated granitic clasts. Unit 7 contains in-

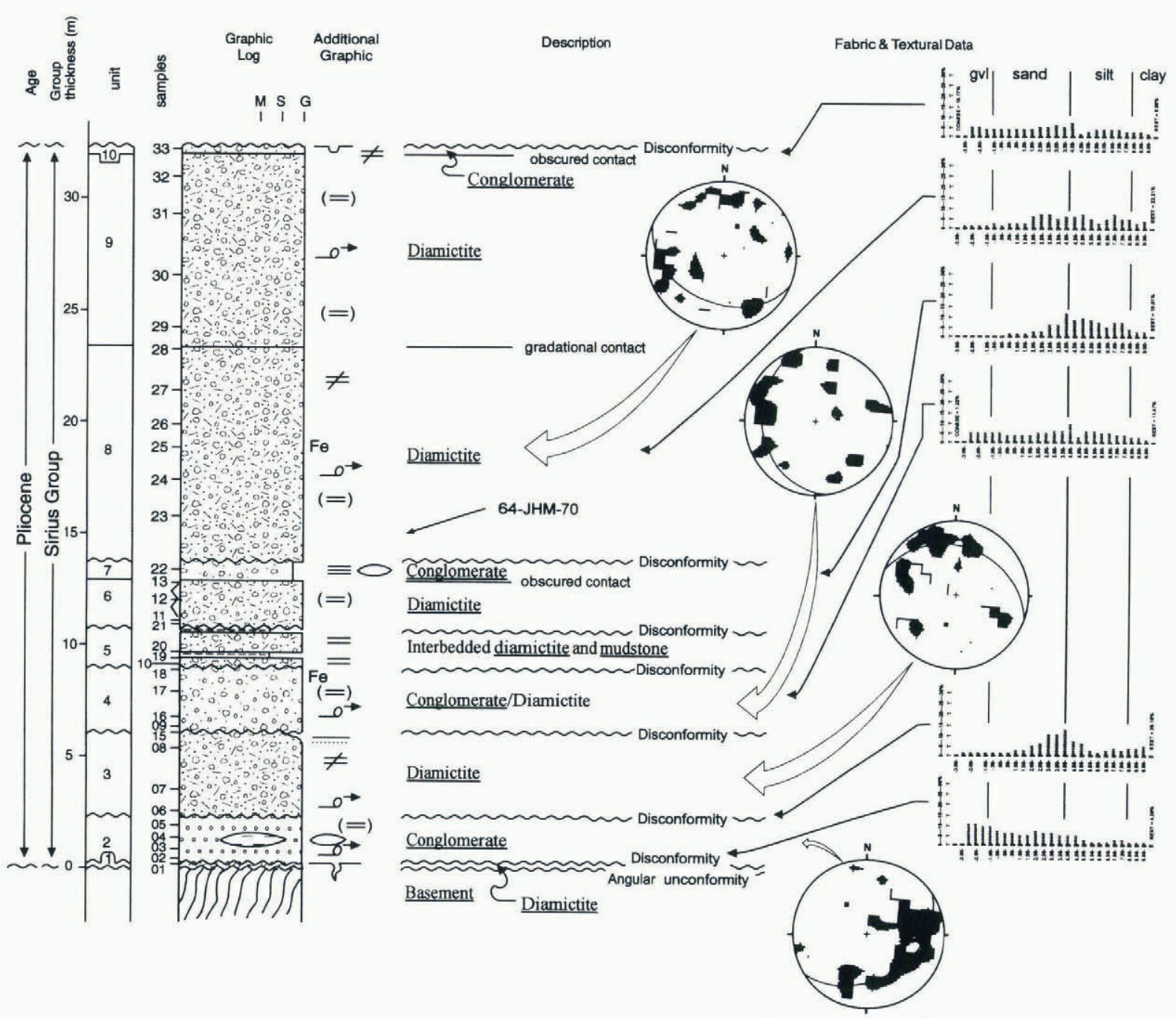

Fig. 2. Stratigraphic column of the type section of the Tillite Spur Formation exposed at Tillite Spur. Additional graphic symbols are those standardly used in stratigraphic column description (e.g. Andrews, 1982). Fabric data are from 300 pebble AB plane measurements plotted on an equal-area stereographic projection azimuth (poles to plane) with a contour interval of $2 \%$ per $1 \%$ area. Texture is graphed as weight per cent in $\frac{1}{2} \phi$ intervals from combined dry-sieving and sedigraph analysis of the matrix fraction of samples. Weight percent coarser than $4 \phi$ is reported as coarse and weight per cent finer than $10 \phi$ is reported as rest. 


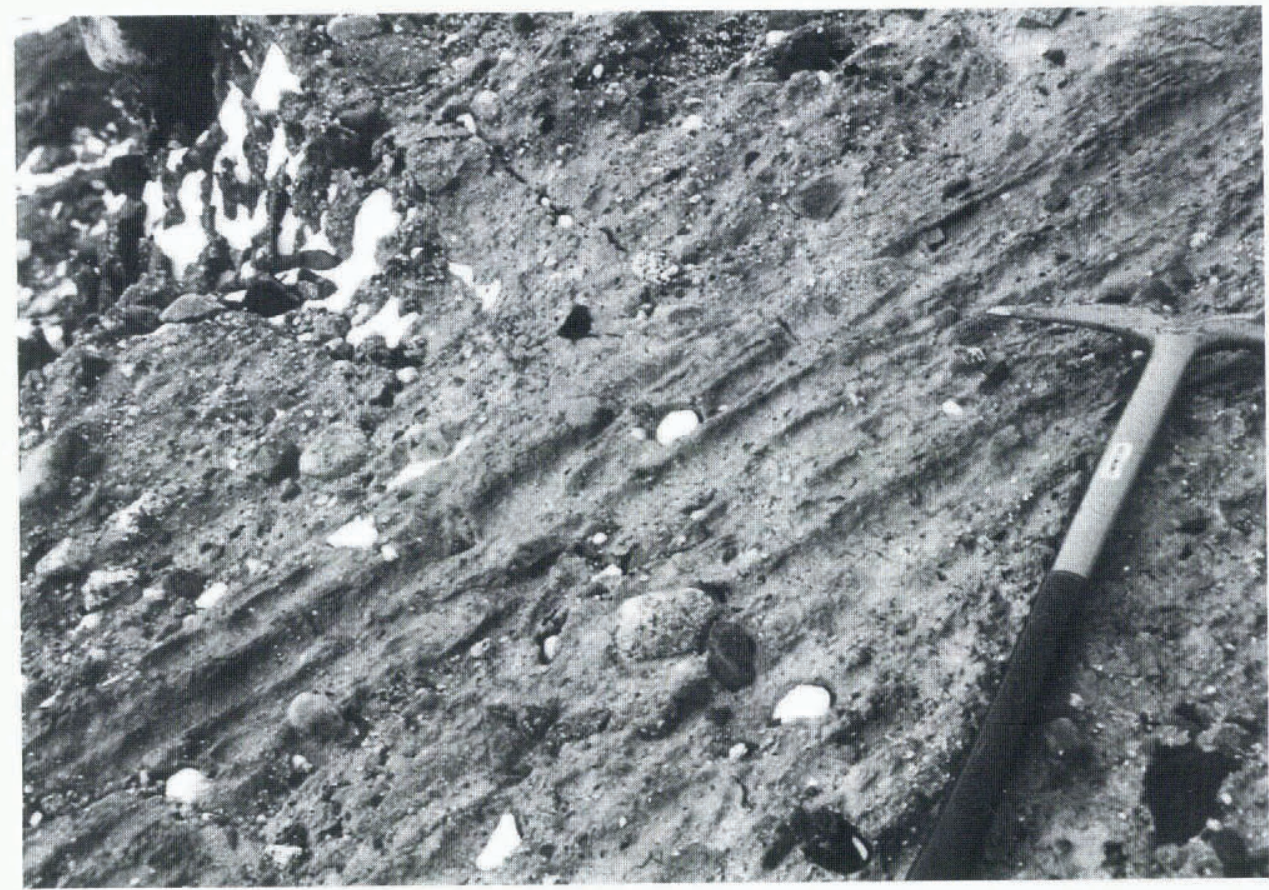

Fig. 3. Glacial grooves cross-cutting Tillite Spur Formation (Sirius Group) strata at Tillite Spur. Surface depicted is inclined at $70^{\circ}$. Flow direction is from bottom left to top right. Handle of geologic pick is $1 \mathrm{~m}$ long.

terbedded conglomerate and sandstones. The conglomerate matrices are locally muddy and sandy, and the sandstones are poorly sorted and contain occasional dropstones. Unit 15 is a sedimentary breccia. At Quartz Hills, it is $1.5 \mathrm{~m}$ thick but thickens in an up-valley direction. Units 8, 10, 12 and 14 are rhythmites (interbedded laminated mudstones and sandstones). Individual bed thicknesses vary between 1 and $50 \mathrm{~mm}$, and sandier beds fine upwards and often grade into laminated mudstones. Stratification in the rhythmic sequences is commonly disrupted and sandstones often contain rip-up clasts of laminated mudstones from underlying beds. These units contain occasional dropstones. Unit 14 also contains $1-3 \mathrm{~m}$ thick lenses of diamictite. Units 2 and 4 are laminated, sandy mudstones without sandstone interbeds. Unit 17 and the upper $2 \mathrm{~m}$ of unit 14 are strongly bioturbated, sandy, micaceous mudstones, with occasional sand stringers, ripple-bed forms and sand-filled burrows.

\section{LITHOFACIES}

\section{Diamictite}

Diamictite is the commonest facies in both the Tillite Spur (81\% of sequence; Fig. 5a) and Quartz Hills exposures (65\% of sequence). The diamictites are mostly massive but exhibit occasional faint stratification. Texturally, the diamictites are very poorly sorted, matrix supported, moderately sandy $(20-40 \%$ of the matrix is sand) but are often quite muddy $(20-75 \%$ of the matrix is silt and clay). Stratification is marked by discontinuous muddy, sandy and/or gravelly horizons. Individual diamictite units almost always have erosional basal contacts and at Quartz Hills rip-up clasts occur in the basal part of some diamictite units. At Tillite Spur, mudstone horizons that mark stratification in unit 5 are olive-gray, sheared, vary between 10 and $30 \mathrm{~cm}$ in thickness, and are often inclined up to $20^{\circ}$. The color of individual diamictite units at Tillite Spur varies with clastand sand-grain petrography. Brownish yellow diamictites with a weathered appearance contain a high proportion of clasts and sand grains that have been derived from Beacon Supergroup rocks. Fresher-looking gray micaceous diamictites that contain a high proportion of granitic material have been derived from nearby granitic basement rocks. All the diamictite units at Quartz Hills have a gray color and fresh appearance. The diamictites have a weak fabric and vary between no imbrication to a poorly defined imbrication (Fig. 2).

\section{Conglomerate}

This facies is very similar to the diamictite but separated here because it comprises more than $50 \%$ clasts and is clastsupported. It is present at both Tillite Spur (19\% of sequence) and Quartz Hills (5\% of sequence; Fig. 5b). Texturally, this facies is poorly sorted like the diamictite facies but much coarser in appearance (less than $30 \%$ of the matrix is silt and clay) and contains moderate to frequent sand lenses up to $3 \mathrm{~m}$ long that provide a distinct stratification. Clasts are generally small $(<30 \mathrm{~cm}$ in diameter), sub-rounded to sub-angular, occasionally angular (sedimentary breccia) and rarely striated. Granitic clasts are dominant and the matrix is commonly quartz-rich, giving the facies a fresh gray color in outcrop. Rip-up clasts of mudstone from underlying units and formations are common. At Tillite Spur, the clasts are moderately imbricated with a westerly flow direction indicated (Fig. 2).

\section{Rhythmite (interbedded laminated mudstones and sandstones)}

This facies was only observed at Quartz Hills and comprises $24 \%$ of the sequence (Fig. 5c). Units of this facies are locally conformable with underlying strata or have loaded bases and overlie the underlying diamicts with erosional contacts. Individual mudstone beds are sandy, $1-30 \mathrm{~cm}$ thick and generally fine upwards. The upper part of the mudstone beds, when fine enough, are laminated on millimeter laminations and are occasionally convoluted or developed into flame structures from loading by overlying mudstones and sand- 


\section{QUARTZ HILLS FORMATION}

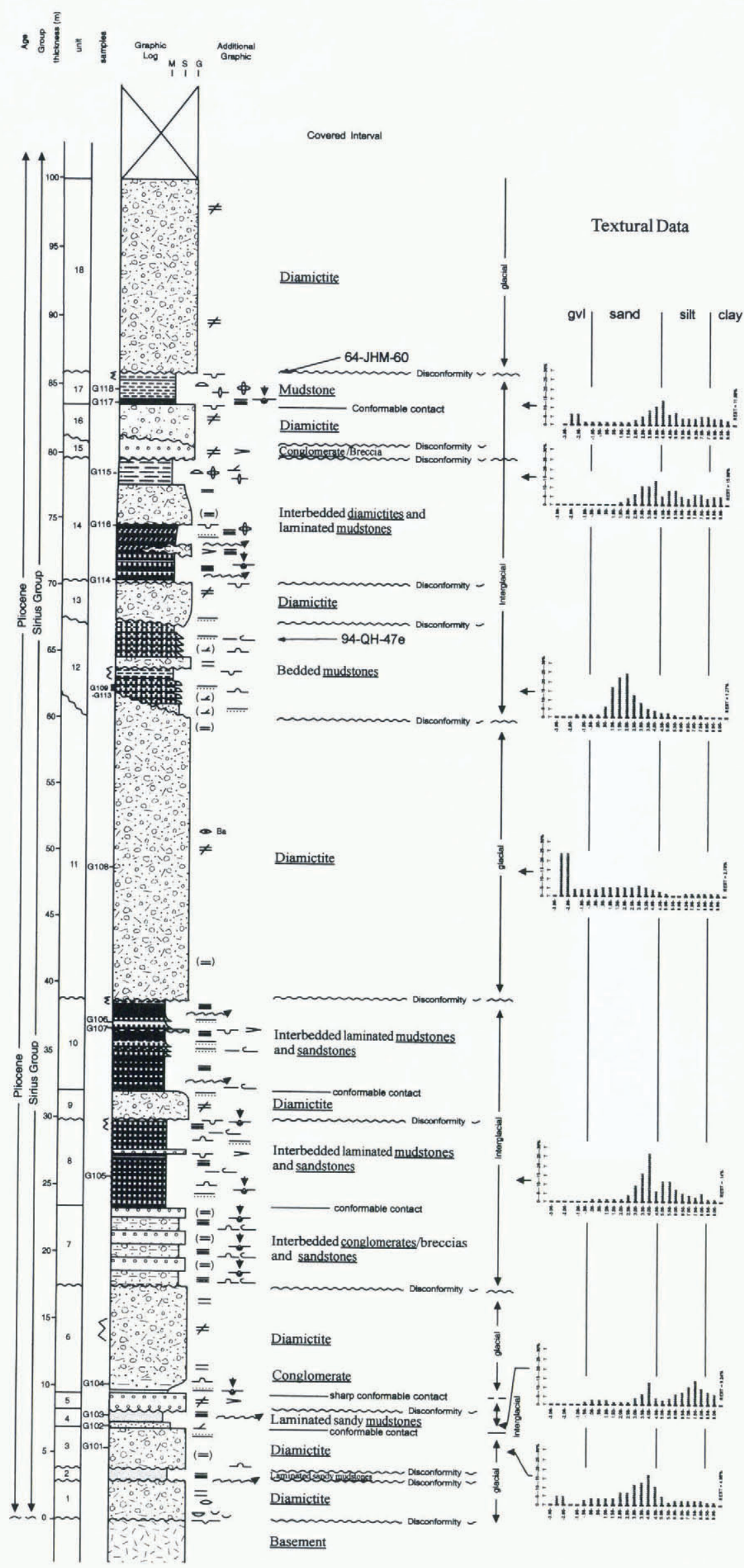

Fig. 4. Stratigraphic column of the type section of the Quartz Hills Formation exposed at Quartz Hills. Additional graphic symbols are those standardly used in stratigraphic column description (e.g. Andrewes, 1982). Texture is graphed as weight per cent in $\_\phi$ intervals from combined dry-sieving and sedigraph analysis of the matrix fraction of samples. Weight per cent coarser than $4 \phi$ is reported as coarse, and weight per cent finer than $10 \phi$ is reported as rest. 

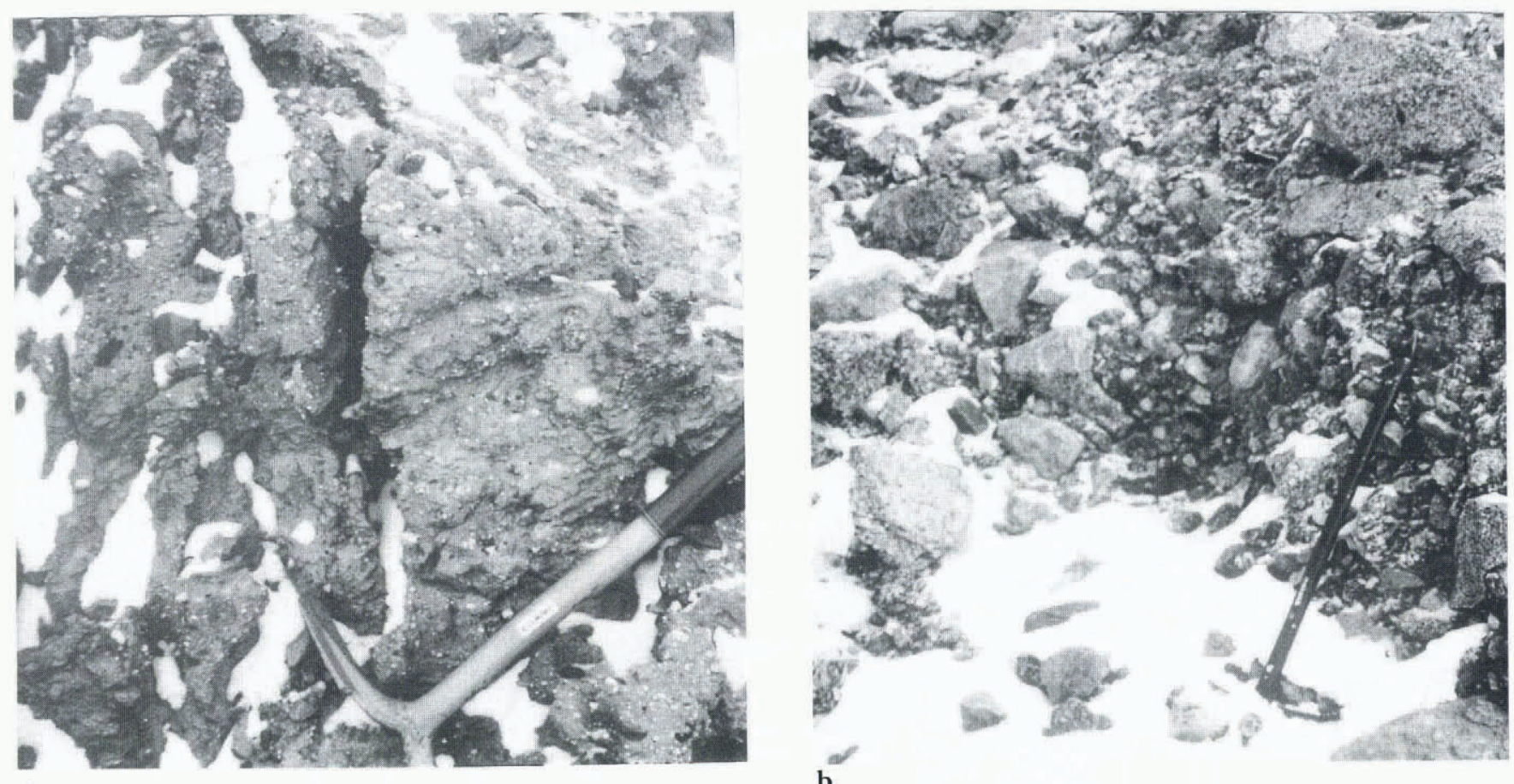

a

b

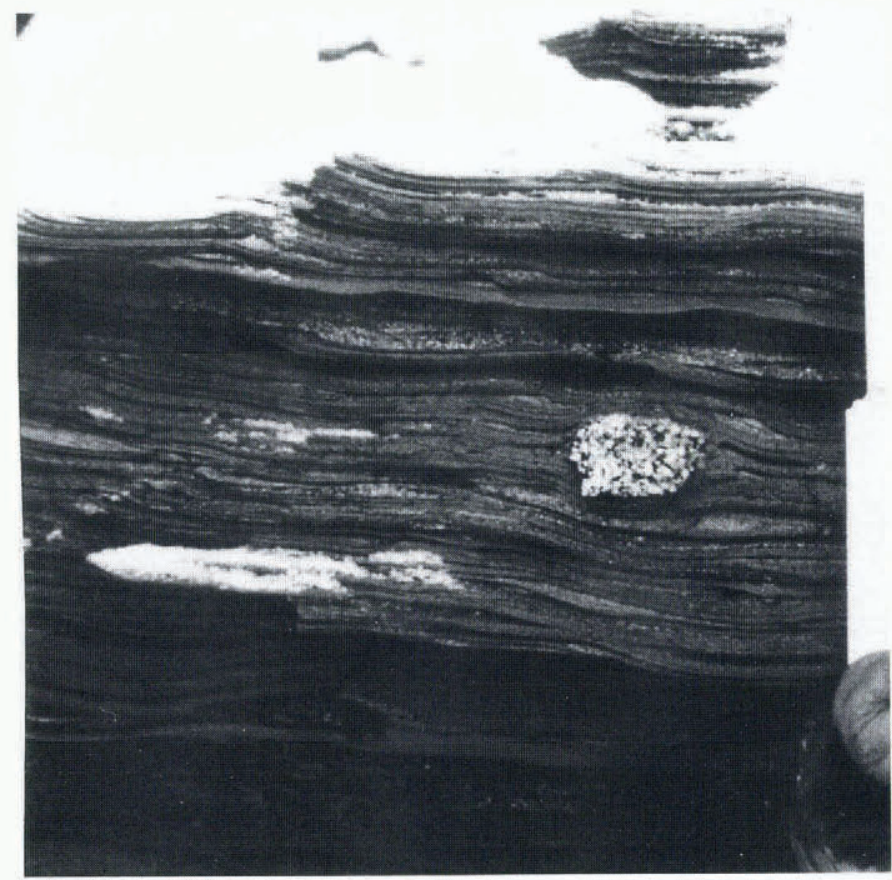

c

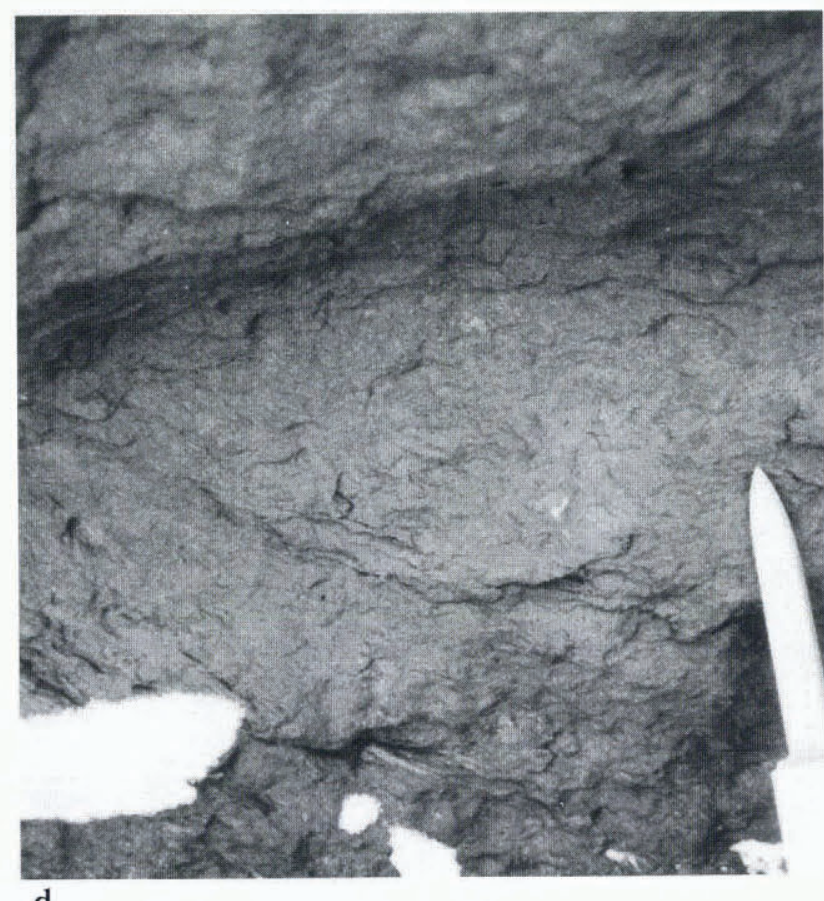

d

Fig. 5. Examples of sedimentary facies from the Quartz Hills and Tillite Spur Formations: (a) a massive, poorly sorted, matrixsupported, moderately sandy diamictite from the Tillite Spur Formation (unit 8). Handle of geologic pick is $1 \mathrm{~m} l o n g ;(b)$ a massive, poorly sorted, clast-supported, sandy conglomerate from the lower section of the Quartz Hills Formation (unit 6). Handle of geologic pick is $1 \mathrm{~m}$ long; (c) rhythmic interbedded laminated mudstones and sandstones from the Quartz Hills Formation (unit 8). Thicker sand interbeds are a sequence of sand ripples. Granite dropstone in right center of picture is $3 \mathrm{~cm}$ in diameter and deforms underlying beds by $1 \mathrm{~cm}$. Overlying mud drapes have $1 \mathrm{~cm}$ of relief; (d) bioturbated sandy mudstone with occasional end sections of sand-filled burrows visible from the upper section of the Quartz Hills Formation (upper part of unit 14). Knife blade is $7.5 \mathrm{~cm}$ long.

stones. Sandstone units also grade upwards. They are less common than the laminated mudstone horizons and generally have sharp unconformable bases often with small "ripup" clasts from underlying laminated mudstone beds. They fine upwards into the laminated mudstone facies.

\section{Bioturbated sandy mudstone}

This facies was only observed at Quartz Hills and comprises $5 \%$ of the described sequence (Fig. $5 \mathrm{~d}$ ). It is a massive, poorly sorted, micaceous, slightly gravelly, very sandy mudstone that is strongly bioturbated. Most stratification has been destroyed by the bioturbation. Occasional sand stringers and concave lenticular sand hummocks (Fig. 6a) delineate a horizontal stratification. Some larger burrows are sand-filled and in unit 17 at Quartz Hills an identifiable burrow is preserved in outcrop (Fig. 6b). The visible part of the burrow is $30 \mathrm{~cm}$ long, straight, gently dipping and contains a "turn-around" partway along its length and several $3 \mathrm{~cm}$ diameter interlocking chambers at its deepest extent. 

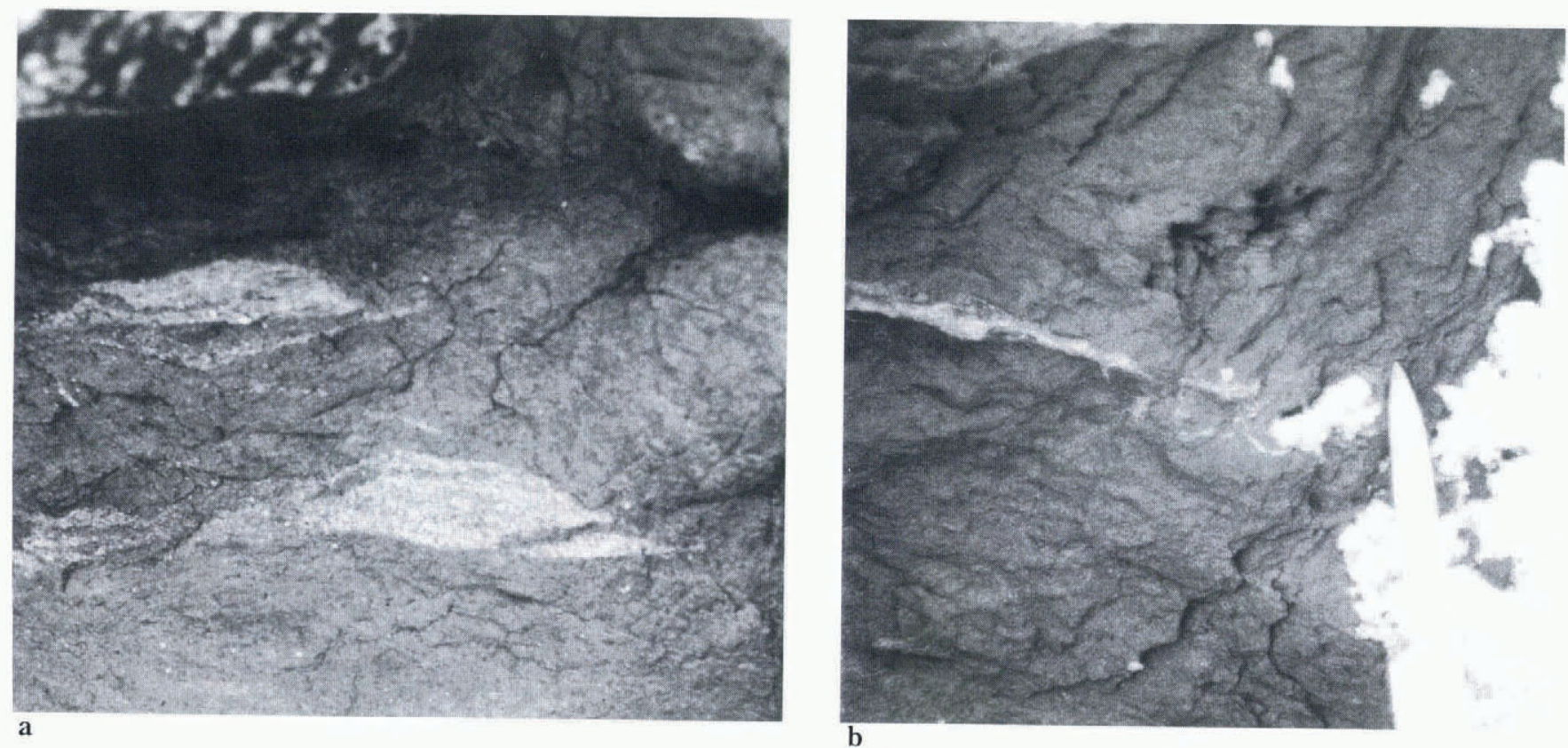

Fig. 6. Sedimentary structures from unit 17 of the Quartz Hills Formation: (a) $3 \mathrm{~cm}$ tall, concave lenticular sand hummocks; (b) $15 \mathrm{~cm}$ long sand-filled decapod burrow with a lurn-around preserved towards the lefthand end; lower chambers in the center of the picture are c. $2.5 \mathrm{~cm}$ across.

\section{Sandstone}

This facies was rare and comprised only $1 \%$ of the sequence described at Quartz Hills. Sandstones are stratified, muddy, poorly sorted and contain occasional small dropstones. Stratification is locally convoluted and sandstones sometimes exhibit flaser bedding.

\section{MICROPALEONTOLOGY}

\section{Palynomorphs}

Sixteen samples were processed and examined for palynomorphs, ten from Quartz Hills and six from Tillite Spur. Samples were processed using standard palynological techniques. Moderate amounts of organic matter, almost all recycled from the Beacon Supergroup, were recovered from the six samples from Tillite Spur. In each case, the organic matter consists of mainly brown to black finely disseminated debris. Other organic matter (samples TS-26 and 27) includes mainly black fragments, with rare brown woody material, rare palynomorphs (Fig. 7) and rare yellowish plant tissue in samples TS-26 and TS-29. The palynomorphs recovered from the Tillite Spur samples can be grouped into three assemblages of differing thermal maturation: (1) recycled dark brown to brownish black Permian Beacon Supergroup spores and pollen, (2) recycled yellow to orange-yellow Paleogene pre-Sirius Group spores and pollen, (3) extremely rare yellow, possibly in-situ, spores and pollen.

Recycled Beacon Supergroup palynomorphs occur in all Tillite Spur samples and include spores and taeniate bisaccate pollen (Fig. 7l) consistent with a Permian age. The recycled pre-Tillite Spur Formation Paleogene palynomorphs include specimens of Nothofagidites spp., Proteacidites subscabratus, other angiosperm pollen, podocarpaceous conifer pollen and cryptogram spores (e.g. Cyathidites minor and Retitriletes sp.). Five of the six samples analyzed from Tillite Spur contain possible in-situ Neogene Sirius palynomorphs: sample TS-13 contains a single specimen of angiospermous pollen of unknown affinity, sample TS-20 contains a single specimen of triporate angiospermous pollen, sample TS-23 contains possible algal remains and cryptogram spores, and samples TS-26 and TS-29 contain angiospermous pollen and cryptogram spores.

Samples from Quartz Hills were essentially barren of organic matter. Extremely rare organic material includes: two specimens of an angiosperm pollen of unknown affinity in sample QH-104 and a specimen each of Podocarpidites sp. (Fig. $7 \mathrm{~m}$ ) and Chenopodiaceae pollen in sample QH-105. The conifer specimen is similar to that recovered from Sirius Group sediments from Oliver Bluffs by Askin and Markgraf (1986).

\section{Siliceous microfossils}

Siliceous marine microfossils have been recovered from 11 samples, ten (including three previously collected by Mercer) from Tillite Spur and a single sample previously collected by Mercer from Quartz Hills. Fifteen other samples (12 from Tillite Spur and three from Quartz Hills) were found to be barren of siliceous microfossils. Samples were prepared by disaggregation, sieving and various density-settling techniques as described by Harwood and others (1986). Siliceous microfossil assemblages recovered include marine diatoms (Fig. 7), silicoflagellates, chrysophycean cysts, radiolarians, ebridians, freshwater diatoms, sponge spicules and pieces of marine sediment containing abundant diatoms. The assemblage compositions in the sediment clasts are similar to the isolated diatoms, suggesting a common source. It is likely that the isolated diatoms were derived from disaggregation of the sedimentary clasts, which occurred during glacial transport or laboratory preparation.

Diatom abundances were generally very low (approximately 30 diatoms per sample) but five of the bulk samples from Tillite Spur yielded more than 50 diatoms per slide. Samples containing siliceous sedimentary microclasts were more productive than samples from which no microclasts were recovered. The most productive sample 64-JHM-70, collected from $15 \mathrm{~m}$ above the base of the Tillite Spur sequence (Fig. 2), contained diverse early Oligocene, Miocene 
and Pliocene marine diatom assemblages (Harwood, 1983, 1986). Of the marine species recovered, Rhizosolenia oligocaenica, Sphynctolethus pacificus (Fig. 7f), Stephanopyxis eocena and S. hyalomarginata are known from the late Eocene to the early Oligocene; Denticulopsis dimorpha (Fig. 7k), D. simonsenii and D. lauta are Miocene; Fragilariopsis barronii, Thalassiosira inura (Fig. 7d), T. fascicualata, T. kolbei and T. torokina (Fig. 7a) are Pliocene to middle Pleistocene; T. insigna, T. vulnifica (Fig. 7e) and $F$. praeinterfrigidaria (Fig. $7 \mathrm{j}$ ) are restricted to the Plio- cene; and T. oliverana, T. lentiginosa (Fig. 7c), F. kerguelensis and Actinocyclus actinochilus (Fig. $7 \mathrm{~b}$ ) range from the Pliocene to recent. T. vulnifica, F. kerguelensis and A. actinochilus are the youngest taxa identified. All first appear in the Southern Ocean and on the Antarctic shelf after 3.1 Myr (Harwood and Maruyama, 1992; Winter and Harwood, 1997).

The only sample from Quartz Hills that yielded marine diatoms was 64-JHM-60 collected from fine-grained strata close to the top of the sequence at Quartz Hills described
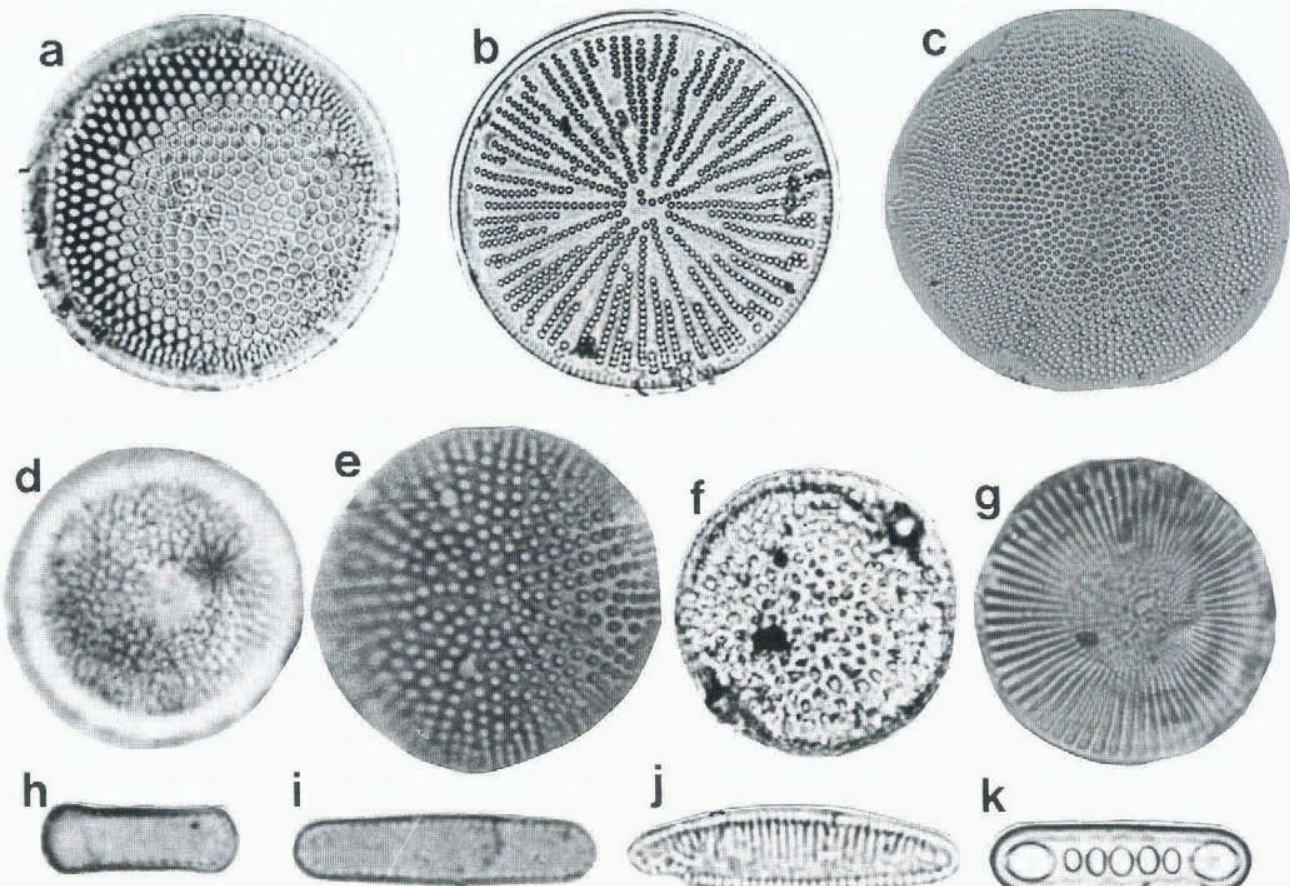

i
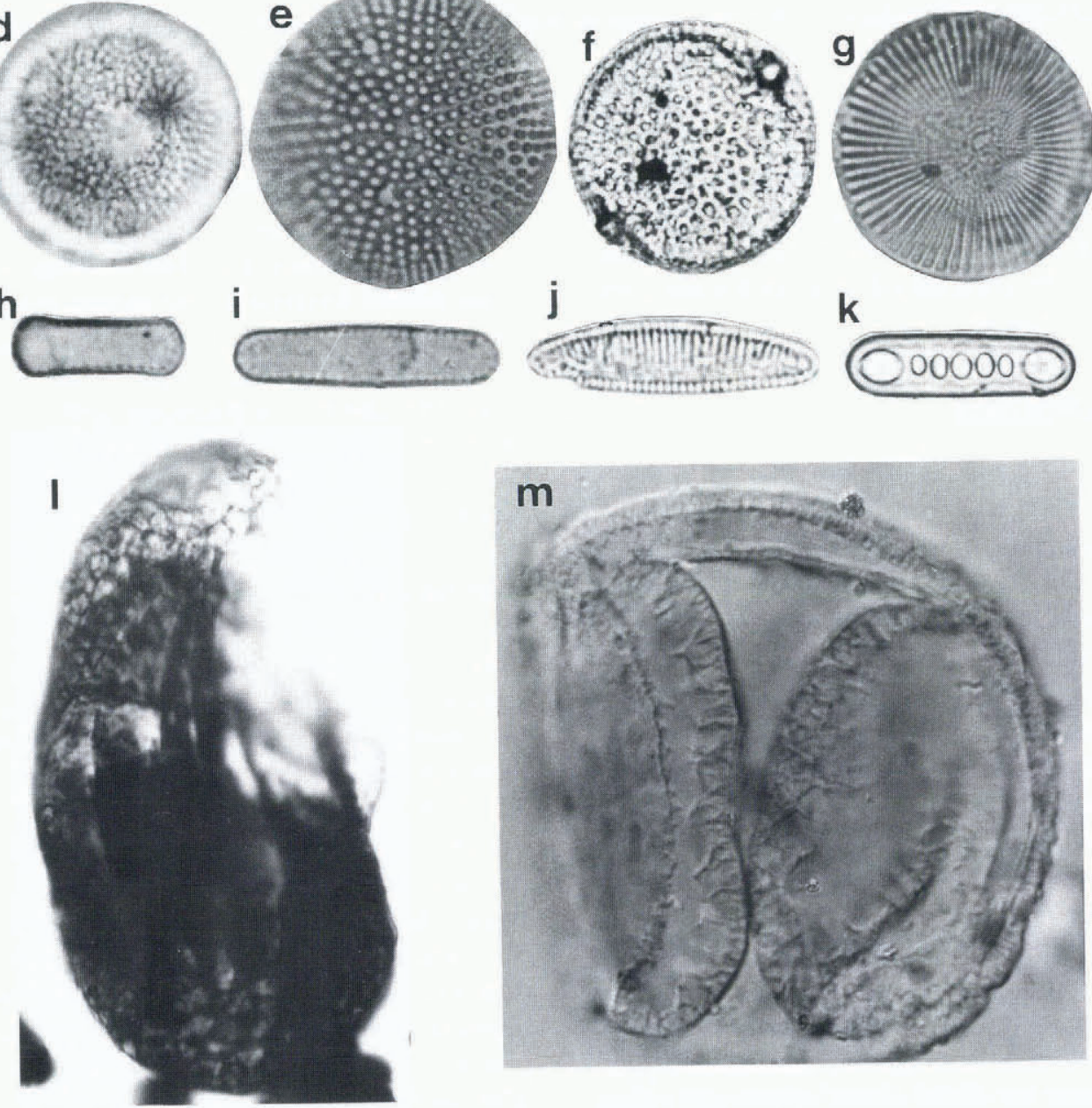

Fig. 7. Microfossils recovered from the Tillite Spur and Quartz Hills Formations, Sirius Group, Reedy Glacier area. Diatoms: (a) Thalassiosira torokina Brady, Quartz Hills Formation, sample 64 JHM60; 100 pm diameter. (b) Actinocyclus actinochilus (Ehrenberg) Simonsen, Quartz Hills Formation, sample 64JHM60; 90 um diameter. (c) Thalassiosira lentiginosa (Janisch) Fryxell, Tillite Spur Formation, sample 64 JHM70; $100 \mu \mathrm{m}$ diameter. (d) Thalassiosira inura Gersonde, Tillite Spur Formation, sample TS-2, $30 \mu$ m diameter. (e) Thalassiosira vulnifica (Gombos) Fenner, Tillite Spur Formation, $64 \mathrm{JHM} 70,50 \mu \mathrm{m}$ diameter. ( $f$ ) Sphynctolethus pacificus (Hajos) Sims, Tillite Spur Formation, 64JHM70, $45 \mu \mathrm{m}$

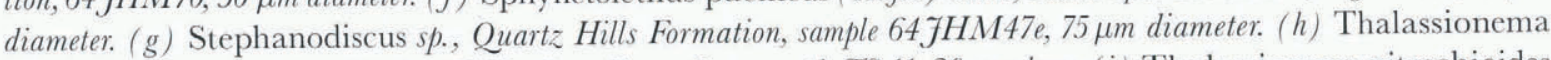
nitzschoides var. parva Heiden, Tillite Spur Formation, sample TS-11, 20 mm long. (i) Thalassionema nitzschioides (Grunow), Tillite Spur Formation, sample TS-7, 25 mm long. ( j) Fragilariopsis pracinterfrigidaria (McCollum), Tillite Spur Formation, sample 64JHM70, $45 \mu \mathrm{m}$ long. (k) Denticulopsis dimorpha Schrader, Tillite Spur Formation, 647HM70, 55 um long. Palynomorphs: (l) Protohaploxypinus sp. (taeniate bisacate) pollen, sample TS-26, $64 \mu \mathrm{m}$ long. (m) Podocarpidites sp. pollen, Quartz Hills Formation, sample QH-105, 52 um diameter. 
here (Fig. 4). The diatom assemblage includes the Plio-Pleistocene species Actinocyclus actinochilus, T. lentiginosa, T. oestrupii and T. torokina. Samples from units 8, 10 and 12 at Quartz Hills yielded only fresh-water diatoms. Sample 94QH47e contained well-preserved Stephanodiscus sp. (Fig. $7 \mathrm{~g}$ ), which is a Neogene fresh-water form (Bradbury and Krebs, 1995).

\section{DISGUSSION}

The diamicts of the Tillite Spur Formation record two ice sources. The gray conglomerates were deposited by an alpine glacier, that flowed west across Tillite Spur and was locally fed from a catchment on the Wisconsin Plateau. This glacier may have carved the paleo-valley within which the Tillite Spur Formation sits and then later deposited the gray conglomerates. Striae on the paleo-valley floor and pebble fabric demonstrate that the glacier flowed westward from the Wisconsin Plateau. The finer-grained, matrix-supported, brown-olive diamictites are weakly imbricated. The imbrication demonstrates that they were deposited by northward-flowing ice, most likely the paleo-Reedy Glacier, when it flowed at higher levels, or alternatively when the Wisconsin Plateau region was at a lower elevation.

The conglomerates sourced from the Wisconsin Plateau have a low proportion of fine particle sizes. There are several possible reasons for this: (1) the units may have been deposited by cold, dry alpine ice that did not produce many fines, (2) the glacier had warmer ice and fines which were winnowed during deposition, or (3) it may be a result of the granitic source bedrock material. Diamictites of the paleoReedy Glacier ice contain a high mud content and the units are stratified, suggesting that the sediment is not from a local source. We interpret the alternating sequence of diamictites and conglomerates in the Tillite Spur Formation to represent glacial-interglacial cycles with ice-deriving sediment, alternately from nearby alpine sources, and more distal Reedy Glacier paleo-valley sources, respectively.

The exposure face of the Tillite Spur Formation exhibits glacial grooves from a more recent glacial episode. This was perhaps related to the initial down-cutting by Olentangy Glacier, which responded in turn to the most recent downcutting phase of Reedy Glacier to its current level.

The diatoms recovered from the Tillite Spur Formation are from the finer-grained matrix-supported brown-olive diamictite units deposited by the northward-flowing paleoReedy Glacier. Imbrication measurements from this study support the hypothesis of Webb and others (1984) that these marine flora are sourced from the Pensacola Basin to the south behind the Transantarctic Mountains. They represent phases of reduction in the East Antarctic ice sheet at times of marine productivity and subsequent erosion, transport and redeposition into the glacigenic strata deposited by the paleo-Reedy Glacier within the Tillite Spur Formation of the Sirius Group. Paleogene palynomorphs identified in this study must also have originated from south of the Transantarctic Mountains.

In the Quartz Hills Formation, we interpret the finely stratified/rhythmic interbedded mudstones and sandstones (units 8,10,12 and 14) to have been deposited in a proglacial lake. We conclude that these deposits are lacustrine, because only fresh-water diatoms were recovered from these beds and, while rhythmic and relatively undisturbed sequences with minimal or no organic matter, have been documented in marine settings (Mackiewicz and others, 1984), they are also indicative of lacustrine settings (Schlüchter, 1979). We also suggest that they were deposited in a lake that occupied much of the paleo-Reedy Glacier valley because, if the lake only occupied the area of the paleo-cirque, sedimentation would have been dominated by lodgement to proximal glacial sediments derived from a Reedy Glacier ice margin.

Nearby glacial activity is indicated by dropstones in the stratified glacial units (units 8, 10, 12 and 14) (Fig. 5c) and interbedded coarse conglomerate and diamictite units (units 7,9,11,13 and 14) (Fig. 5a and b). We interpret the fining-upwards lensoid coarse sand to conglomerate units with rip-up clasts and a scoured base to be turbidite deposits from a local glacial ice margin. The massive finer-grained matrix supported diamictites, we interpret to have been deposited as lodgement tills when the ice margin advanced and grounded across the proglacial lake. We suggest these alternating stratified sequences and thick massive tills represent glacial-interglacial cycles in the Quartz Hills Formation. They are interpreted as advance and retreat episodes of the paleo-Reedy Glacier, respectively, covering and re-exposing a large proglacial lake. At this stage, we are uncertain of the relationship between the glacial-interglacial cycles in the strata at Quartz Hills and Tillite Spur.

The introduction of burrowing organisms into the upper part of the sequence at Quartz Hills is marked by the very pronounced bioturbation in the uppermost unit 14, and throughout unit 17 (Fig. 4). Lower in the sequence, similar rhythmic strata are devoid of bioturbation. The sand-filled burrows observed in unit 17 were produced by a decapod (personal communication from R. Feldmann, 1997). The burrows are unlined, inclined and have an outer diameter of $\mathrm{C}$. $10 \mathrm{~mm}$. They have an open framework, are infilled by material of a different texture to the surrounding matrix and the networks contain turn-arounds, branches and terminal chambers, all features which are indicative of decapods from shallow neritic and littoral environments (cf. Weimer and Hoyt, 1964; Frey and Mayou, 1971; Griffis and Suchanek, 1991; Myrow, 1995). Given the cold and essentially vegetation-free environment indicated by the Quartz Hills sequence, we conclude that terrestrial migration of burrowing organisms and introduction into this previously organism-free environment is unlikely. Therefore, the lake must have been close to sea level and the burrowing (including decapod) life forms were introduced into the environment by a marine incursion. Given the nature of the burrows and the sedimentary associations, we also hypothesize (from comparison with modern-day occurrences (Weimer and Hoyt, 1964; Frey and Mayou, 1971) that these organisms lived close to the berm. This conclusion means that the lowest bioturbated horizon in the Quartz Hills Formation is also a sea-level datum in the sequence. This horizon now sits at about $1600 \mathrm{~m}$ a.s.l., indicating significant uplift since their deposition.

The only age constraint available for both the Tillite Spur and Quartz Hills Formations is the Pliocene diatom flora. This flora was suggested as having been reworked into the Sirius Group strata from marine sedimentary basins now behind the Transantarctic Mountains, beneath the East Antarctic ice sheet (Webb and others, 1984). Their incorporation into the glacial strata provides a maximum age of Middle Pliocene for the Tillite Spur Formation and may provide a direct age for shallow fiordal sediments in the upper units of the Quartz Hills Formation, if the flora are "in-situ" at this location. However, recent studies have de- 
monstrated that some diatoms can be reworked on to exposed geologic surfaces in Antarctica by eolian processes (Burckle and Potter, 1996; Kellogg and Kellogg, 1996; Stroeven and others, 1996; Barrett and others, 1997), and it has recently been hypothesized that the diatoms may have been emplaced on exposed geologic surfaces in Antarctica as impact ejecta fall-out (Gersonde and others, 1997).

Several factors suggest that the diatom flora in the Tillite Spur and Quartz Hills Formations were introduced into the strata at the time of deposition rather than by subsequent eolian or impact processes: (1) several age-restricted floras are present, necessitating a source containing strata of diverse ages. Such a source is not currently exposed for eolian deflation on the Antarctic craton; (2) an Eocene-Oligocene marine flora is relatively abundant in one sample only from the Tillite Spur Formation. Other occurrences are not uniform in abundance or age ranges of taxa recovered; (3) numerous samples are barren of diatom flora and not uniformly distributed at the surface; (4) sample 64-JH-70 contains abundant flora (more than 50 diatoms per slide, compared to two-three diatoms per slide for wind-blown marine diatoms (Burckle and Potter, 1996), or a few diatoms per $\mathrm{cm}^{2}$ for ejecta fall-out (Gersonde and others, 1997), that we feel must have originated from marine sedimentary clasts or in the case of the Quartz Hills Formation may represent an "in-situ" marine occurrence; (5) in the Tillite Spur and Quartz Hills Formations, samples are dominated by marine floras, whereas samples used to demonstrate colian processes are dominated by fresh-water and marine coastal flora (Kellogg and Kellogg, 1996; Barrett and others, 1997; Gersonde and others, 1997); (6) our samples were collected from strata exposed in eroding, near-vertical cliff faces (with no weathering of the exposed face and no diagenetic modification or intergranular mobility behind the eroding face) rather than on altered sub-horizontal geologic surfaces (Stroeven and others, 1996; Barrett and others, 1997); (7) several diatomaceous sediment clasts (illustrated in Harwood (1986)) are more than $100 \mu \mathrm{m}$ in diameter - a size too large to be wind-blown or penetrate the diamicton (Burckle and others, 1988).

\section{CONCLUSIONS}

The Tillite Spur and Quartz Hills Formations are two very different sequences of the Sirius Group. The Tillite Spur Formation strata are thin and non-stratified, and similar in appearance to Sirius Group sediments described from the Dry Valleys area (Mayewski, 1975; Brady and McKelvey, 1979, 1983). They were deposited in an alpine elevated glacial setting in the Transantarctic Mountains (Mercer, 1978) and represent alternating intramontane and trunk-valley basin sediments similar to the model proposed by Webb (1994). Quartz Hills Formation strata are more similar in appearance to Cloudmaker Formation strata from the Beardmore Glacier region (Webb and others, 1996). The Quartz Hills Formation strata were deposited in a lacustrine/fiord setting and represent advance and retreat in a trunk-valley delta basin system similar to the model proposed by Webb (1994). Such a setting is much lower in elevation than that envisaged for the Tillite Spur Formation.

The Tillite Spur and Quartz Hills Formations record advances of a paleo-Reedy Glacier. Both formations are Pliocene or younger but it is not known whether they are temporal equivalents. Recycled marine diatom flora (some in clasts) in the diamictites were deposited by an advanced paleo-Reedy Glacier. The diatom flora record several episodes of marine deposition behind the Transantarctic Mountains (the source of the glacigene Tillite Spur and Quartz Hills formation sediments) during times in the Cenozoic when this area of the Antarctic interior must have been icefree (cf. Webb and others, 1984). Marine strata in the upper units of the Quartz Hills Formation indicate at least $500 \mathrm{~m} \mathrm{Myr}^{-1}$ of uplift of the Queen Maud Mountains of the Transantarctic Mountains since middle Pliocene times. More recently, Reedy Glacier and associated glaciers have down-cut at least $500 \mathrm{~m}$, in response to the Pliocene-Pleistocene uplift, and exposed the Sirius Group strata described here. These strata were probably not exposed until the middle late Pleistocene.

Three orders of paleoclimatic variability are recorded in the Sirius Group strata from Reedy Valley: (1) recycled marine microfloras in glacial diamictites indicate intervals of marine incursion into the Antarctic cratonic interior cooccurring with reductions in the East Antarctic ice sheet; (2) an advancing and retreating paleo-Reedy Glacier deposited a glacial-interglacial sequence alternating on a 10 $100 \mathrm{kyr}$ scale; (3) centimeter and millimeter stratification in strata of the Quartz Hills Formation record annual kyr scale variability. As yet, we do not understand the temporal relationships of the Tillite Spur and Quartz Hills formations (except that they are both middle-late Pliocene in age). However, Reedy Glacier represents an important place to investigate the relationship between high-altitude alpine facies and lower-elevation trunk-valley (marine) facies of the Sirius Group strata as they both crop out in the same valley system. Such a study should significantly improve our understanding of the paleoenvironmental and paleoclimatic significance of Sirius Group strata in different and disconnected geographical and temporal settings. However, as is made clear from this study, interpretations of one Sirius Group outcrop should not be imposed on other geologically and geographically different outcrops of Sirius Group strata.

\section{ACKNOWLEDGEMENTS}

J. DeVries and S. Bohaty assisted with field work. Field work, and D.M.H. and R.H.L., were supported by U.S. National Science Foundation grant OPP9158075 to D.M.H. and donations from the U.N.L. geology alumni. G.S.W. acknowledges support from the Byrd Fellowship (OSU).

\section{REFERENCES}

Andrews, P. B. 1982. Revised guide to recording field observations in sedimentary sequences. N. Z. Geol. Surv. Rep. 102.

Askin, R. A. and V. Markgraf. 1986. Palynomorphs from the Sirius Formation, Dominion Range, Antarctica. Antarct. J. U.S., 21 (5), 34-35.

Barrett, P. J.. N. L. Bleakley, W.W. Dickinson, M. J. Hannah and M. A. Harper. 1997. Distribution of siliceous microfossils on Mount Feather, Antarctica, and the age of the Sirius Group. In Ricci, C. A., ed. The Antarctic region: geological evolution and processes. Siena, Museo Nazionale dell' Antartide, $763-770$.

Bradbury, J. P. and W. N. Krebs. 1995. Fossil continental diatoms: paleolimnology, evolution, and biochronology. In Blome, C. P., P. A. Whalen and K. M. Reed, eds. Siliceous microfossils, Knoxville, TN, University of Tennessee. Paleontological Society, 119-138. (Short Course in Paleontology 8.)

Brady, H. and B. C. Mc Kelvey. 1979. The interpretation of Tertiary tillite at Mount Feather, southern Victoria Land, Antarctica. J. Glaciol., 22 (86), $189-193$.

Brady, H. and B. Mc Kelvey. 1983. Some aspects of the Cenozoic glaciation 
of southern Victoria Land, Antarctica. 7. Glaciol., 29 102, 343-349.

Burckle, L. H. and N. Potter, Jr. 1996. Pliocene-Pleistocene diatoms in Paleozoic and Mesozoic sedimentary and igneous rocks from Antarctica: a Sirius problem solved. Geology, 24 (3), 235-238.

Burckle, L. H., R. I. Gayley, M. Ram andJ.-R. Petit. 1988. Diatoms in Antarctic ice cores: some implications for the glacial history of Antarctica. Geolog), 16 4), 326-329.

Carlquist, S. 1987. Upper Pliocene-lower Pleistocene. Nothofagus wood from the Transantarctic Mountains. Aliso, 11 (4), 571- 583.

Clapperton, C. M. and D. E. Sugden. 1990. Late Cenozoic glacial history of the Ross embayment, Antarctica. Quat. Sci. Rev., 9 2-3), $253-272$.

Denton, G. H., M. L. Prentice, D. E. Kellogg and T. B. Kellogg. 1984. Late Tertiary history of the Antarctic ice sheet: evidence from the dry valleys. Geolog), 12 (5), 263267.

Denton, G. H., D. E. Sugden, D. R. Marchant, B. L. Hall and T. I. Wilch. 1993. East Antarctic ice sheet sensitivity to Pliocene climatic change from a dry valleys perspective. Geogr. Ann., 75A (4), 155-204.

Doumani, G. A. and V. H. Minshew. 1965. General geology of the Mount Weaver area, Queen Maud Mountains, Antarctica. In Geology and paleontology of the Antartic. Washington, DC, American Geophysical Union, 127-139. (Antarctic Research Series 6.)

Francis, J. E. and R. S. Hill. 1996. Fossil plants from the Pliocene Sirius Group, Transantarctic Mountains: evidence for climate from growth rings and fossil leaves. Palaios, 11 4),389-396.

Frey, R.W. and T.V. Mayou. 1971. Decapod burrows in Holocene barrier island beaches and washover fans, Georgia. Senckenbergiana Marit., 3, 53- 77.

Gersonde, R. and 12 others, 1997. Geological record and reconstruction of the Late Pliocene impact of the Eltanin asteroid in the Southern Ocean. Nature, 390 6658), 357-363.

Griffis, R. B. and T. H. Suchanek. 1991. A model of burrow architecture and trophic modes in thalassinidean shrimp (Decapoda: Thalassinidea). Mar. Ecol. Prog. Ser., 79, 171-183.

Harwood, D. M. 1983. Diatoms from the Sirius Formation, Transantarctic Mountains. Antarct. 7. U.S., 18 (5), 98-100.

Harwood, D. M. 1986. Recycled siliceous microfossils from the Sirius Formation. Antart. J. U.S., 21 (5), 101-103.

Harwood, D. M. 1991. Cenozoic diatom biogeography in the southern high latitudes: inferred biogeographic barriers and progressive endemism. In Thomson, M. R. A., J. A. Crame and J. W. Thomson, eds, Geological evolution of Antartica. Cambridge, Cambridge University Press, 667-673.

Harwood, D. M., M.W. Grant and M.H. Karrer. 1986. Techniques to improve diatom recovery from glacial sediments. Antarcl. 7. U.S., 21 (5), $107-108$.

Harwood, D. M. and T. Maruyama. 1992. Middle Eocene to Pleistocene diatom biostratigraphy of Southern Ocean sediments from the Kerguelen Plateau, Leg 120. In Wise, S. W. and R. Schlich, eds. Ocean Drilling Program. Proceedings. Scientific Resulls. Vol. 120. College Station, TX, Ocean Drilling Program, 683-734.

Harwood, D. M. and P.-N. Webb. 1986. Recycled marine microfossils from basal debris-ice in ice-free valleys of southern Victoria Land. Antarct. 7 . U.S., $21(5), 87-88$.

Harwood, D. M. and P.-N. Webb. 1991. Early interpretations of Antarctic and Arctic glacial history: uniformitarian biases mask a dynamic history of Cenozoic ice-volume variation. Geol. Soc. Am. Abstr. Programs, $25(5), 106$.

Hill, R. S., D. M. Harwood and P.-N. Webb. 1991. Nothofagus beardmorensi. (Nothofagaceae), a new species based on leaves from the Pliocene Sirius Group, Transantarctic Mountains, Antarctica. Rez. Palaeobot. Palynol., $94,11-24$.

Hill, R. S. and E. M. Truswell. 1993. Nothofagus fossils in the Sirius Group, Transantarctic Mountains: leaves and pollen and their climatic significance. In Kennett, J. P. and D. A. Warnke, eds. The Antarctic paleoenvironment: a perspective on global change. Part 2. Washington, DC, American Geophysical Union, 67-73. (Antarctic Research Series 60.)

Kellogg, D. E. and T. B. Kellogg. 1996. Diatoms in South Pole ice: implications for eolian contamination of Sirius Group deposits. Geology, 24 (2), $115-118$.

Kennett, J. P. 1977. Cenozoic evolution of Antarctic glaciation, the circumAntarctic Ocean, and their impact on global paleoceanography. \% Geophys. Res., 82 27), 3843-3860.

Mackiewicz, N. E., R. D. Powell, P. R. Carlson and B. F. Molnia. 1984. Interlaminated ice-proximal glacimarine sediments in Muir Inlet, Alaska. Mar. Geol., 57 (1/4), 113-147.

Marchant, D. R., G. H. Denton, C. C. Swisher, III and N. Potter, Jr. 1996. Late Cenozoic Antarctic paleoclimate reconstructed from volcanic ashes in the Dry Valleys region of southern Victoria Land. Geol. Soc. Am.
Bull., 108(2), 181-194.

Mayewski, P. A. 1972. Glacial geology near McMurdo Sound and comparison with the central Transantarctic Mountains. Antarcl. F. U.S., 7 (4), 103 106.

Mayewski, P. A. 1975. Glacial geology and late Cenozoic history of the Transantarctic Mountains, Antarctica. Ohio State Univ. Inst. Polar Stud. Rep. 56.

McKelvey, B. C., P. N. Webb, D. M. Harwood and M. C. G. Mabin. 1991. The Dominion Range Sirius Group: a record of the Late PlioceneEarly Pleistocene Beardmore Glacier. In Thomson, M. R. A., J. A. Crame and J.W. Thomson, eds. Geological evolution of Antarctica. Cambridge, Cambridge University Press, 675-682.

Mercer, J. H. 1968. Glacial geology of the Reedy Glacier area, Antarctica. Geol. Soc. Am. Bull., 79 4), 471-486.

Mercer, J. H. 1972. Some observations on the glacial geology of the Beardmore Glacier area. In Adie, R. J., ed. Anlarctic geology and geophysics. Oslo, Universitetsforlaget, 427-433. International Union of Geological Sciences, Ser. B, No. 1 .

Mercer, J. H. 1978. Glacial development and temperature trends in Antarctic and in South America. In Van Zinderen Bakker, E. M., Sr, ed. Antarctic glacial history and world palaeoenvironments. Rotterdam, A.A. Balkema, 73-93.

Mercer, J. H. 1981. Tertiary terrestrial deposits of the Ross Ice Shelf area, Antarctica. In Hambrey, M. J. and W. B. Harland, eds. Earth's pre-Pleistocene glacial record. Cambridge, Cambridge University Press, 204-207.

Mercer, J. H. 1983. Cenozoic glaciation in the Southern Hemisphere. Annu. Rev. Earth Planet. Sci., 11, 99-132.

Minshew, V. H. 1966. Stratigraphy of the Wisconsin Range, Horlick Mountains, Antarctica. Science, 152 (3722), 637-638.

Moncrieff, A. C. M. 1989. Classification of poorly sorted sedimentary rocks. Sediment. Geol., 65 1-2, 191-194.

Myrow, P. M. 1995. Thalassinoides and the enigma of Early Paleozoic openframework burrow systems. Palaios, 10, 58-74.

Schlüchter, C., ed. 1979. Moraines and varves: origin/genesis/classification. Rotterdam, A.A. Balkema.

Stroeven, A. P., M.J. Prentice and H.W. Borns, Jr. 1992. Mt. Fleming Upper Valley drift: evidence for Neogene glacial history of Antarctica. Antarct. F. U.S., 27 (5), $51-54$.

Stroeven, A. P., M. L. Prentice andJ. Kleman. 1996. On marine microfossil transport and pathways in Antarctica during the late Neogene: evidence from the Sirius Group at Mount Fleming. Geology, 24 8, 727-730.

Webb, P.-N. 1994. Paleodrainage systems of East Antarctica and sediment supply to West Antarctic rift systems basins. Terra Antartica, 1 2, 457-461.

Webb, P.-N. and D. M. Harwood. 1987. Terrestrial flora of the Sirius Formation; its significance for Late Cenozoic glacial history. Antarct. f. L.S., 22 (5), 7-11.

Webb, P.-N. and D. M. Harwood. 1993. Pliocene fossil Nothofagus (southern beech) from Antarctica: phytogeography, dispersal strategies and survival in high latitude glacial-deglacial environments. In Alden, J., J. L. Mastrantonio and S. Odum, eds. Forest development in cold climates. New York and London, Plenum Press, 135-165. (NATO ASI Series A: Life Sciences 244.

Webb, P. N., D. M. Harwood, B. C. Mc Kelvey, J. H. Mercer and L. D. Stott. 1984. Cenozoic marine sedimentation and ice-volume variation on the East Antarctic craton. Geolog), 12 (5), 287-291.

Webb, P.-N., D. M. Harwood, B. C. McKelvey, M. C. G. Mabin and J. H. Mercer. 1986. Late Cenozoic tectonic and glacial history of the Transantarctic Mountains. Antarct. J. U.S., 21 (5), 99-100.

Webb, P.-N., D. M. Harwood, M. C. G. Mabin and B. C. McKelvey, 1994. Late Neogene uplift of the Transantarctic Mountains in the Beardmore Glacier region. Terra Antartica, 1 (2), 463-467.

Webb, P.-N., D. M. Harwood, M. C. G. Mabin and B. C. Mc Kelvey. 1996. A marine and terrestrial Sirius Group succession, middle Beardmore Glacier -Queen Alexandra Range, Transantarctic Mountains, Antarctica. Mar. Micro-paleontol., $27(1-4), 273-297$.

Weimer, R. J. and J. H. Hoyt. 1964. Burrows of Callianassa major Say, geological indicators of littoral and shallow neritic environments. f. Paleontol., 38 (4),761-767.

Wilch, T. I., D. R. Lux, G. H. Denton and W. C. McIntosh. 1993. Minimal Pliocene-Pleistocene uplift of the dry valleys sector of the Transantarctic Mountains: a key parameter in ice-sheet reconstructions. Geolog), $21(9), 841-844$

Winter, D. M. and D. M. Harwood. 1997. Integrated diatom biostratigraphy of late Neogene drillholes in southern Victoria Land and connection to Southern Ocean records. In Ricci, C. A., ed. The Antarctic region: geological evolution and processes. Siena, Museo Nazionale dell'Antartide. Terra Antarctica Publication, 771-780. 